\title{
THE BILIARY EXCRETION OF BROMSULFALEIN AS A TEST OF LIVER FUNCTION IN A GROUP OF PATIENTS FOLLOWING HEPATITIS OR SERUM JAUNDICE
}

\author{
BY C. WILMER WIRTS, JR., AND BRIAN K. BRADFORD \\ (From the Department of Medicine and the Gastrointestinal Clinic, Jefferson Medical College \\ and Hospital, Philadelphia)
}

(Received for publication February 21, 1948)

Prolonged or permanent impairment of liver function is now known to occur in a variable proportion of patients following an attack of infectious hepatitis or serum jaundice (1-11). However, the incidence of this chronic hepatic disease is not well established because of the difficulty in correlating symptomatology with the available liver function tests or with liver biopsy (12-15).

Of the means available for the study of the posthepatitis patient liver biopsy has gained favor because the positive findings have a concreteness lacking in the chemical liver function studies. However, it is not without risk to the patient and conceivably early alterations in physiology could precede structural hepatic change by many months (16-20).

The bromsulfalein, cephalin flocculation, thymol turbidity and Van den Bergh are the tests generally employed but frequently the abnormality shown is slight, and is not uniformly present when they are run simultaneously. The blood clearance of bromsulfalein is generally considered a highly useful chemical test when liver impairment is minimal (21). However, we have experimental evidence in dogs which suggests that the clearance of bromsulfalein from the blood is probably dependent upon a dual mechanism; first, removal from the blood by the reticulo-endothelial system (Kupfer cells) and second, excretion by the hepatic polygonal cells into the bile and that early hepatic damage can cause severe impairment of the excretion of bromsulfalein in the bile without interfering with its removal from the blood (2224). The cephalin flocculation and thymol turbidity tests are not specific tests of liver function because they have been shown to yield positive results in other diseases. Consequently it has been difficult at times to determine the significance of minimal abnormality when it occurs in only one of these tests $(25,26)$. An elevated serum bilirubin in a post-hepatitis patient is probably a reliable index of altered liver function but it is not often the case that hyperbilirubinemia exists when the other three tests are normal.

Because of these discrepancies it was felt that it would be of interest to test the excretion of bromsulfalein in the bile in a selected group of patients in whom impaired liver function was suspected but difficult to prove.

\section{MATERIAL AND METHOD}

From the hepatitis wards of a military hospital 25 patients were selected because, in spite of continuous treatment for one or two months following an attack of infectious hepatitis (14 patients) or serum jaundice (11 patients) and complete disappearance of icterus of skin and sclera, they were still suspected of having some impairment of liver function.

The patients were divided into four groups on the basis of the following criteria: (1) prolonged persistence of symptoms with normal physical findings and normal routine liver function studies; (2) prolonged abnormal physical findings without accompanying symptoms and with normal routine liver function studies; (3) prolonged abnormal routine liver function studies without symptoms or abnormal physical findings and (4) prolonged abnormal routine liver function studies and physical findings without symptoms.

The method of testing liver function by the biliary excretion of bromsulfalein has been described in detail previously and when further reference is made to it in this paper it will be called the biliary bromsulfalein test $(22,23,27)$. A duodenal tube is passed and the tip located in the duodenum fluoroscopically. A Lyon or Rehfuss tube may be used but the double-lumened Wallace-Diamond tube is preferred because with suction it is possible to prevent contamination of the duodenal contents with gastric juice. A free flow of bile is established in the usual manner employed in performing duodenal biliary drainage. Bromsulfalein is then injected intravenously (in this study $5 \mathrm{mg}$. per kilo of body weight was employed) and a blood sample taken at the end of 30 minutes. Bile is collected in 15-minute fractions and the concentration and total quantity of bromsulfalein excreted in the bile over a two-hour period is calculated.

When employing the $5 \mathrm{mg}$. dose the normal excretion of bromsulfalein presents the following features: (1) 10 
per cent, or less, of the dye remains in the blood at the end of 30 minutes; (2) the dye appears usually, but not invariably, in the bile during the first 15 minutes; (3) it attains a maximum concentration in 45 to 75 minutes, falling subsequently to a relatively low level at two hours; (4) approximately 50 per cent of the quantity injected is excreted in the first hour and approximately 75 per cent in the first two hours. Abnormal excretion is evidenced by one or more of the following phenomena: (1) retention of more than 10 per cent of the dye in the blood at the end of 30 minutes; (2) delayed appearance of the dye in the bile; (3) delayed attainment of the maximum concentration; (4) prolonged high curve (plateau-type) of excretion; (5) subnormal concentration (flat type of curve); (6) abnormally low total excretion in one- or two-hour periods after injection (28).

During the initial phase of observation the patient's progress was followed by clinical appraisal and the determination of the icterus index at approximately weekly intervals. When the patient's general condition showed substantial improvement the quantitative and qualitative Van den Bergh, the thymol turbidity test, as modified by Shank and Hoagland (29), and the blood clearance of bromsulfalein were run at approximately weekly intervals. The following values were considered normal: Van den Bergh qualitative, negative direct; quantitative, $0.2 \mathrm{mg}$. to $0.8 \mathrm{mg}$. per $100 \mathrm{cc}$. serum; thymol turbidity, 0 to 4 units; ${ }^{1}$ bromsulfalein, 10 per cent or less in the serum at the end of 30 minutes. All determinations were made on the Coleman junior spectrophotometer. The biliary bromsulfalein test was not run until the patient was free of icterus of both skin and sclera, and fell into one of the four categories described above; it was then repeated at intervals of five to 14 days.

${ }^{1}$ At the time this work was done normal values for the thymol turbidity test were based on the work of Shank and Hoagland. Since then, several authors have pointed out that values in excess of 2 units (30) or $2 \frac{1}{2}$ units (8) should be construed as abnormal.

\section{RESULTS}

Initially all 25 patients showed an abnormal response to the biliary bromsulfalein test. However, after one to two months of additional treatment 60 per cent showed gradual improvement until the response finally approximated normal. While some improvement was noted in the remaining 40 per cent, they continued to show an abnormal response in spite of the one or two months of additional treatment. Unfortunately it was not possible to follow these patients longer so that a final conclusion as to their ultimate improvement could not be drawn. However, the degree of impairment indicated by this test and the slow improvement noted over the three-month period they were observed suggest that some of them suffered a degree of permanent hepatic damage or that a prolonged period of convalescence would still be necessary before complete recovery took place. At the time this study was undertaken circumstances did not permit applying the test to hepatitis convalescents in whom prolonged liver impairment was not suspected. At present, however, we are engaged in following all hepatitis patients on the medical wards with serial testing by this method.

Instead of recording the voluminous data on each patient a typical case has been selected from each of the four categories and a synopsis of his course in the hospital described.

Group I: Prolonged persistence of symptoms with normal physical findings and normal routine liver function studies (four patients).

TABLE I

Tests on patient M.L. (Group $I)$

\begin{tabular}{|c|c|c|c|c|c|c|c|c|c|c|c|c|c|c|}
\hline \multirow{2}{*}{$\frac{\text { Month }}{\text { Day }}$} & \multicolumn{2}{|c|}{ Aug. } & \multicolumn{4}{|c|}{ Sept. } & \multicolumn{4}{|c|}{ Oct. } & \multicolumn{4}{|c|}{ Nov. } \\
\hline & 24 & 29 & 4 & 11 & 18 & 25 & 3 & 11 & 18 & 23 & 1 & 8 & 12 & 21 \\
\hline $\begin{array}{l}\text { Blood bromsulfalein } \\
\text { Icterus index } \\
\text { Van den Bergh } \\
\text { Indirect } \\
\text { Direct } \\
\text { Thymol turbidity } \\
\text { *Total dye in bile (\%) } \\
1 \text { hr. } \\
2 \mathrm{hr} . \\
\text { Liver tender } \\
\text { Liver palpable } \\
\text { Weight }\end{array}$ & $\begin{array}{r}165 \\
22 \\
\text { pos. } \\
9.9\end{array}$ & $\begin{array}{r}265 \\
36 \\
\text { pos. }\end{array}$ & $\begin{array}{l}\text { yes } \\
\text { yes }\end{array}$ & $\begin{array}{l}\text { yes } \\
\text { yes }\end{array}$ & $\begin{array}{l}\text { sl. } \\
\text { yes }\end{array}$ & $\begin{array}{l}\text { sl. } \\
\text { sl. }\end{array}$ & $\begin{array}{c}6.5 \\
\text { pos. }\end{array}$ & $\begin{array}{c}\text { no } \\
\text { no } \\
206\end{array}$ & $\begin{array}{c}15 \\
\frac{1.5}{1.8}\end{array}$ & $\begin{array}{l}18 \\
\frac{0.7}{1.3} \\
16 \\
47 \\
\text { no } \\
\text { no }\end{array}$ & $\begin{array}{l}11 \\
\frac{0.4}{1.2}\end{array}$ & $\begin{array}{c}9 \\
\frac{0.8}{1.3}\end{array}$ & $\begin{array}{l}10 \\
\frac{0.9}{1.4} \\
13 \\
49 \\
\text { no } \\
\text { no }\end{array}$ & $\begin{array}{c}0.8 \\
2.0 \\
18 \\
61 \\
\text { no } \\
\text { no } \\
212\end{array}$ \\
\hline
\end{tabular}

* Biliary bromsulfalein test. 
M. L., a 19-year-old infantryman, was wounded in action, sustaining a perforating wound of the right upper arm with transection of the brachial artery. He received plasma on the day of injury and whole blood two weeks later. $\mathrm{He}$ was returned to this country and a neurorrhaphy of the right median and ulnar nerves was performed. One month later, the patient noted that his sclera were icteric and his urine dark and a diagnosis of serum jaundice was made. Following a stormy course he appeared to improve objectively but three months following the onset of jaundice he still complained of persistent malaise, headache, inability to concentrate and nausea, belching and fullness after meals.

Although this patient had normal routine liver function studies and revealed no abnormal physi- cal findings two months after the onset of symptoms (Table I), the initial biliary bromsulfalein test showed considerable impairment of liver function on the basis of poor total excretion of dye as well as an abnormal concentration curve. Approximately one month later there was considerable improvement in the concentration but the total quantity of dye excreted during the first hour was still much less than normal (Figure 1).

Group II: Prolonged abnormal physical findings without symptoms and with normal routine liver function studies (six patients).

G. W., a 25-year-old white infantryman, was admitted with a compound fracture of the left medial malleolus sustained in action on Luzon. $\mathrm{He}$ received plasma the day he was injured. Jaundice, anorexia, nausea and dark urine devel-

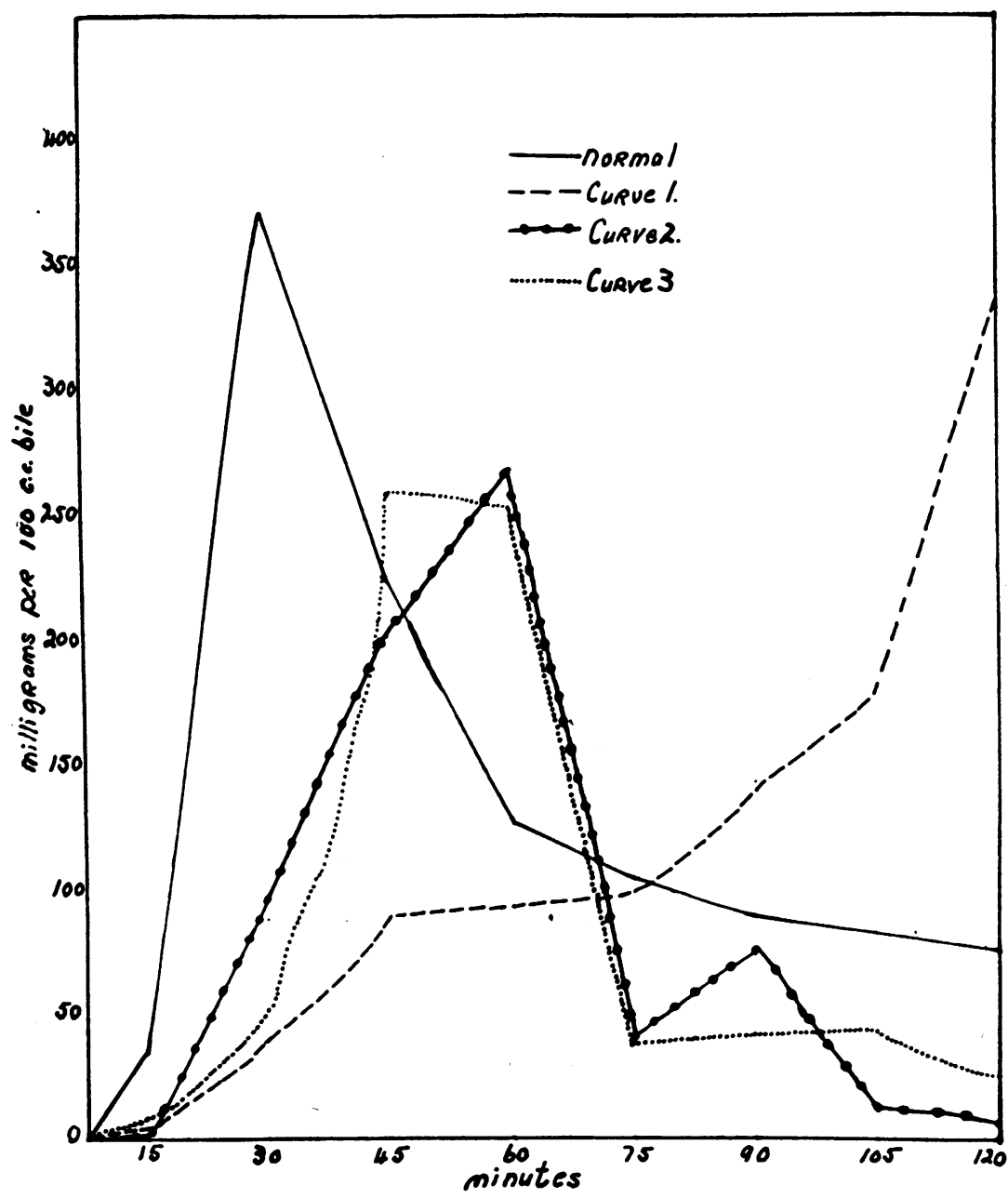

Fig. 1. Comparison of the Biliary Bromsulfalein Curves of Patient M. L. with Normal Curve 
TABLE II

Tests on patient G. W. (Group II)

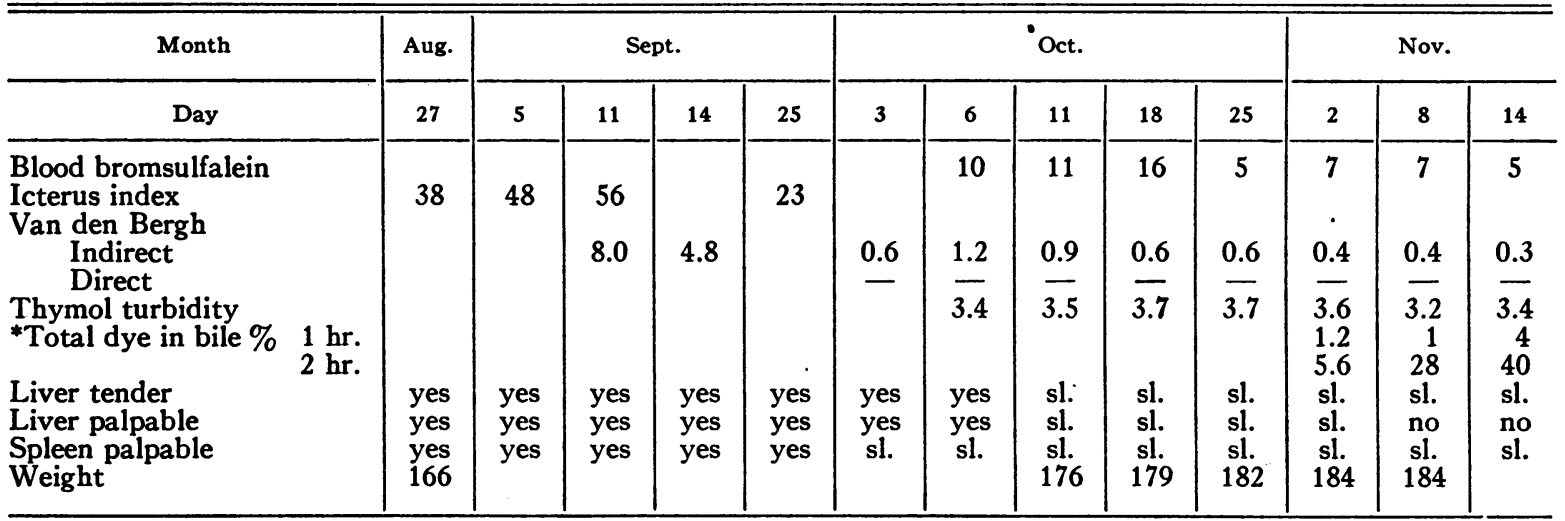

* Biliary bromsulfalein test.

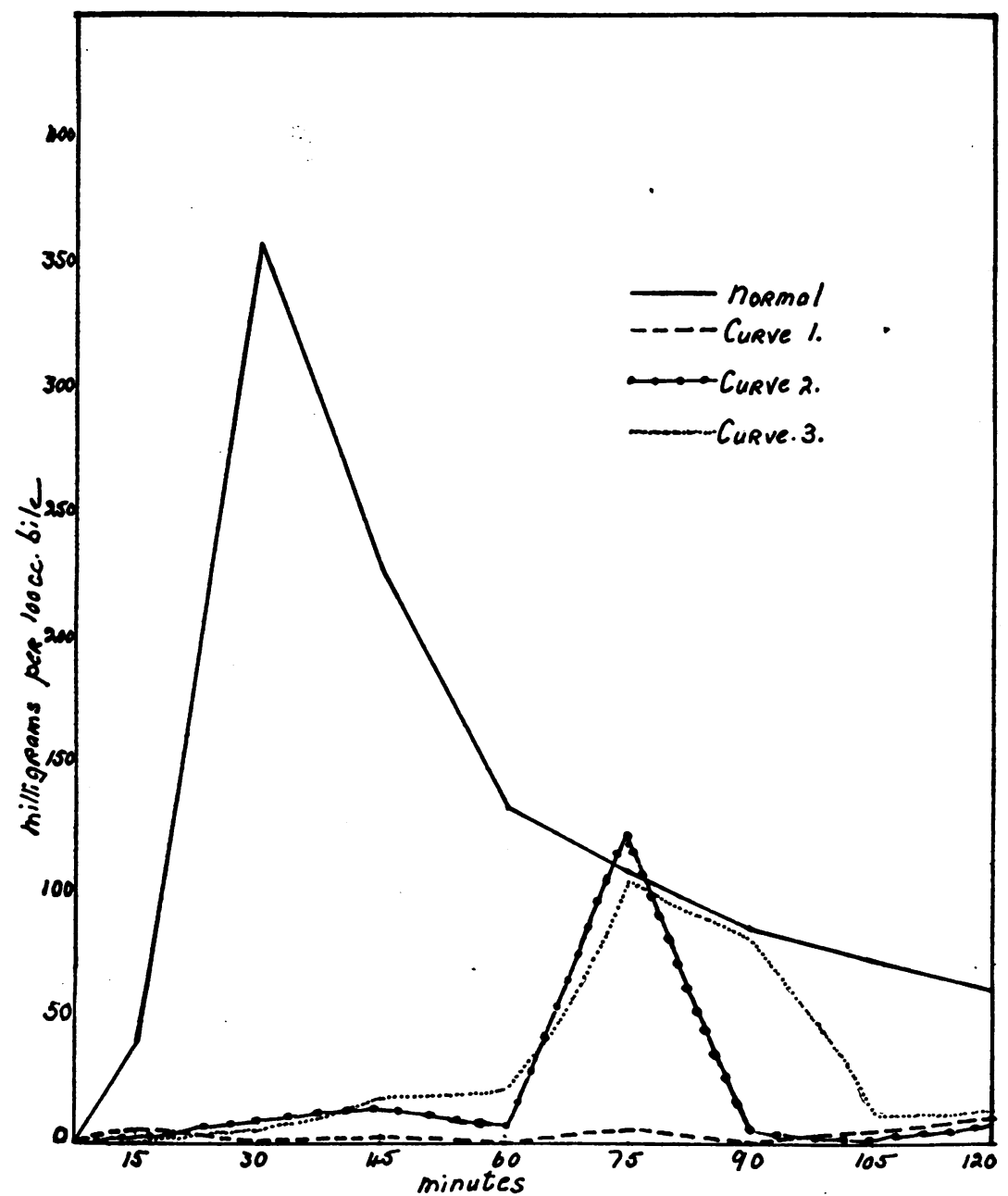

Fig. 2. Comparison of the Biliary Bromsulfalein Curves of Patient G. W. with Normal Curve 
oped five weeks later, while the patient was on the orthopedic ward in a military hospital in this country. Physical examination revealed an enlarged and tender liver and an enlarged spleen. A diagnosis of serum jaundice was made. The patient's convalescence was uneventful except for the persistence of the enlargement and tenderness of the liver and the splenomegaly for a period of over three months.

Although the routine liver function studies were within normal limits (Table II), the biliary bromsulfalein test showed severe impairment of liver function. On the initial test very little of the dye was excreted at all during the test period, so that the concentration curve was almost flat. During the next two weeks there was an increase in the total dye excreted in the two-hour period but the concentration curve remained definitely abnormal (Figure 2).

Group III: Prolonged abnormal routine liver function studies without symptoms or abnormal physical findings (seven patients).

D. M., a 24-year-old paratrooper, was a prisoner-of-war in Germany for six months during which time he developed "trench foot" and lost 30 pounds in weight. While on a hospital train following liberation he developed nausea and vomiting and was noted to be jaundiced. Since he had not received blood or plasma a diagnosis of infectious hepatitis was made. After a month's hospitalization he was symptom-free and was returned to this country. Here physical examination was normal and he was permitted a month's furlough. When he returned liver function studies were performed and found to be abnormal.
Because of this patient's history of infectious hepatitis he was subjected to routine liver function studies before discharge in spite of the fact that he was free of symptoms and abnormal physical findings. These studies revealed an abnormal retention of bromsulfalein in the serum and an abnormal thymol turbidity (Table III). The initial biliary bromsulfalein test, performed after approximately three months' hospitalization, showed moderate impairment of liver function. This improved strikingly over a period of slightly more than a month of continued therapy. The final test was considered within normal limits (Figure 3).

Group IV: Prolonged abnormal liver function studies and physical findings without symptoms (eight patients).

R. K., a 21-year-old paratrooper, was a prisoner-of-war in Germany for four and one-half months, during which time he lost 55 pounds in weight and was in contact with other prisoners who developed jaundice. Two weeks after liberation, the patient developed fever, anorexia, nausea, vomiting, jaundice and pain in the right upper quadrant of the abdomen. A diagnosis of infectious hepatitis was made and the patient was hospitalized for a month and a half before he showed sufficient improvement to permit his return to this country. By this time he had regained 45 pounds in weight and his physical examination was within normal limits. A 30-day furlough was granted but when he returned he was found to have an enlarged liver, which was moderately tender. Liver function study revealed an abnormal thymol turbidity test. The patient improved under further hospital care but the

TABLE III

Tests on patient D. M. (Group III)

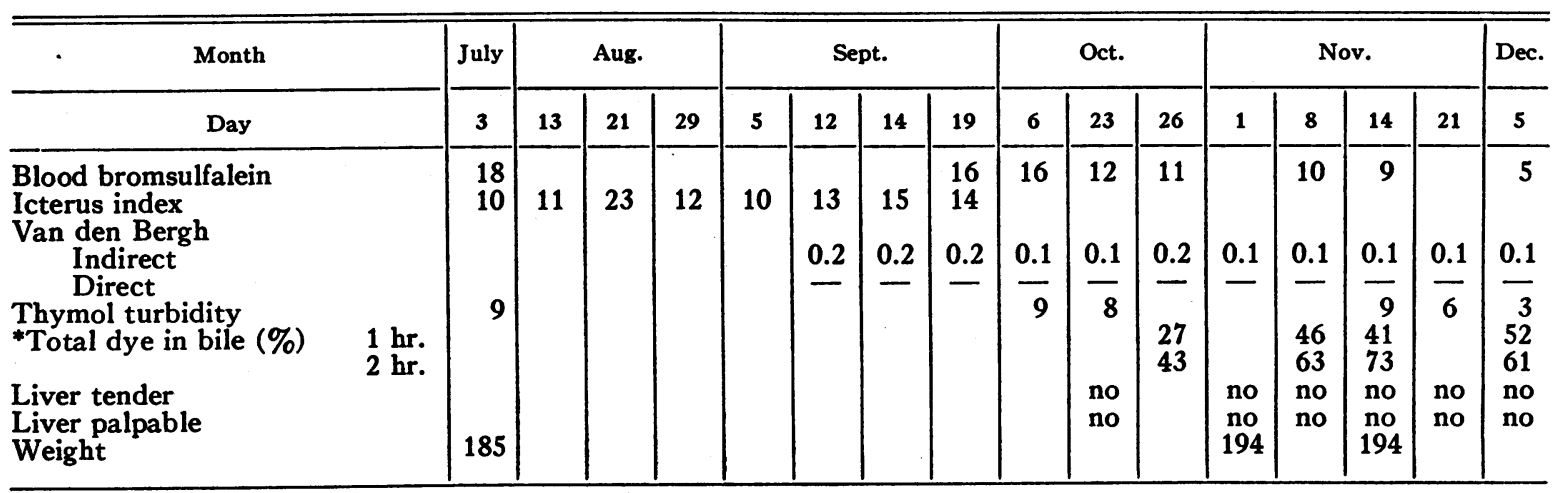

* Biliary bromsulfalein test. 


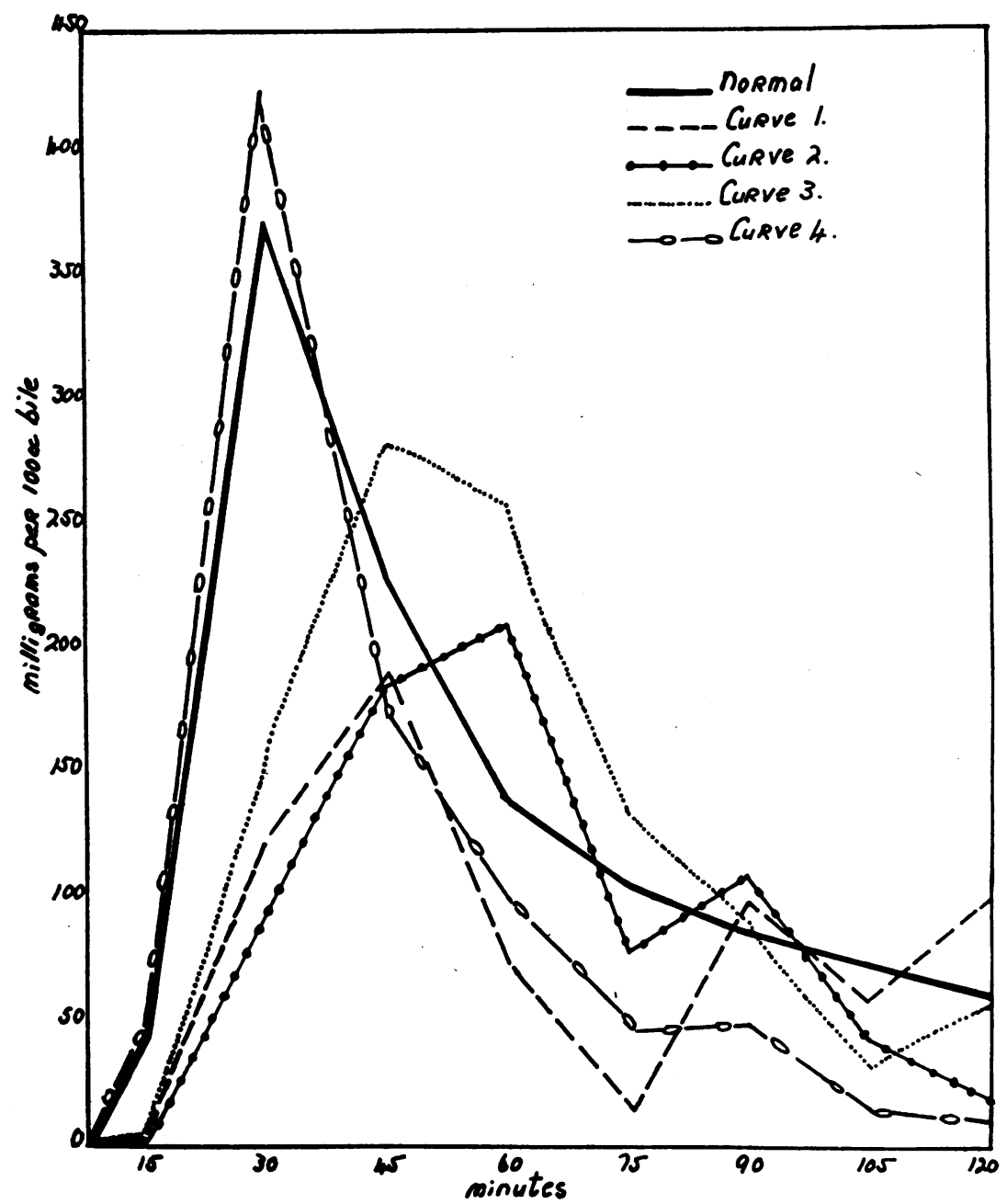

Fig. 3. Comparison of the Biliary Bromsulfalein Curves of Patient D. M. with Normal Curve

TABLE IV

Tests on patient R. $K$. (Group IV)

\begin{tabular}{|c|c|c|c|c|c|c|c|c|c|c|c|c|c|c|c|c|}
\hline \multirow{2}{*}{$\frac{\text { Month }}{\text { Day }}$} & & \multicolumn{2}{|c|}{ Aug. } & \multicolumn{3}{|c|}{ Sept. } & \multicolumn{6}{|c|}{ Oct. } & \multicolumn{4}{|c|}{ Nov. } \\
\hline & & 26 & 31 & 6 & 18 & 25 & 3 & 5 & 11 & 18 & 25 & 29 & 6 & 12 & 21 & 29 \\
\hline $\begin{array}{l}\text { Blood bromsulfalein } \\
\text { Icterus index } \\
\text { Van den Bergh } \\
\text { Indirect } \\
\text { Direct } \\
\text { Thymol turbidity } \\
\text { *Total dye in bile (\%) } \\
\text { Liver tender. } \\
\text { Liver palpable } \\
\text { Weight }\end{array}$ & $\begin{array}{l}1 \mathrm{hr} . \\
2 \mathrm{hr} \text {. }\end{array}$ & $\begin{array}{r}13 \\
1.5 \\
\text { pos. }\end{array}$ & $\begin{array}{l}\text { yes } \\
\text { yes }\end{array}$ & $\begin{array}{r}3 \\
16 \\
\frac{1.1}{10}\end{array}$ & $\begin{array}{l}16 \\
0.7 \\
\end{array}$ & $\begin{array}{l}14 \\
1.0 \\
\end{array}$ & $\underline{0.4}$ & $\begin{array}{c}7 \\
\frac{0.1}{7.3}\end{array}$ & $\frac{1.4}{7.8}$ & $\begin{array}{l}\text { sl. } \\
\text { sl. } \\
167\end{array}$ & $\begin{array}{l}\frac{0.9}{7.0} \\
\text { sl. } \\
\text { sl. } \\
168\end{array}$ & $\begin{array}{c}1.1 \\
8.5 \\
6 \\
12 \\
\text { sl. } \\
\text { no } \\
167\end{array}$ & $\begin{array}{c}2.5 \\
8.3 \\
3 \\
35 \\
\text { sl. } \\
\text { no } \\
167\end{array}$ & $\begin{array}{l}6.5 \\
37 \\
\text { no } \\
\text { no }\end{array}$ & $\begin{array}{c}1.7 \\
7.0 \\
27 \\
55 \\
\text { no } \\
\text { no } \\
168\end{array}$ & $\begin{array}{l}4.0 \\
54 \\
69 \\
\text { no } \\
\text { no }\end{array}$ \\
\hline
\end{tabular}

* Biliary bromsulfalein test. 


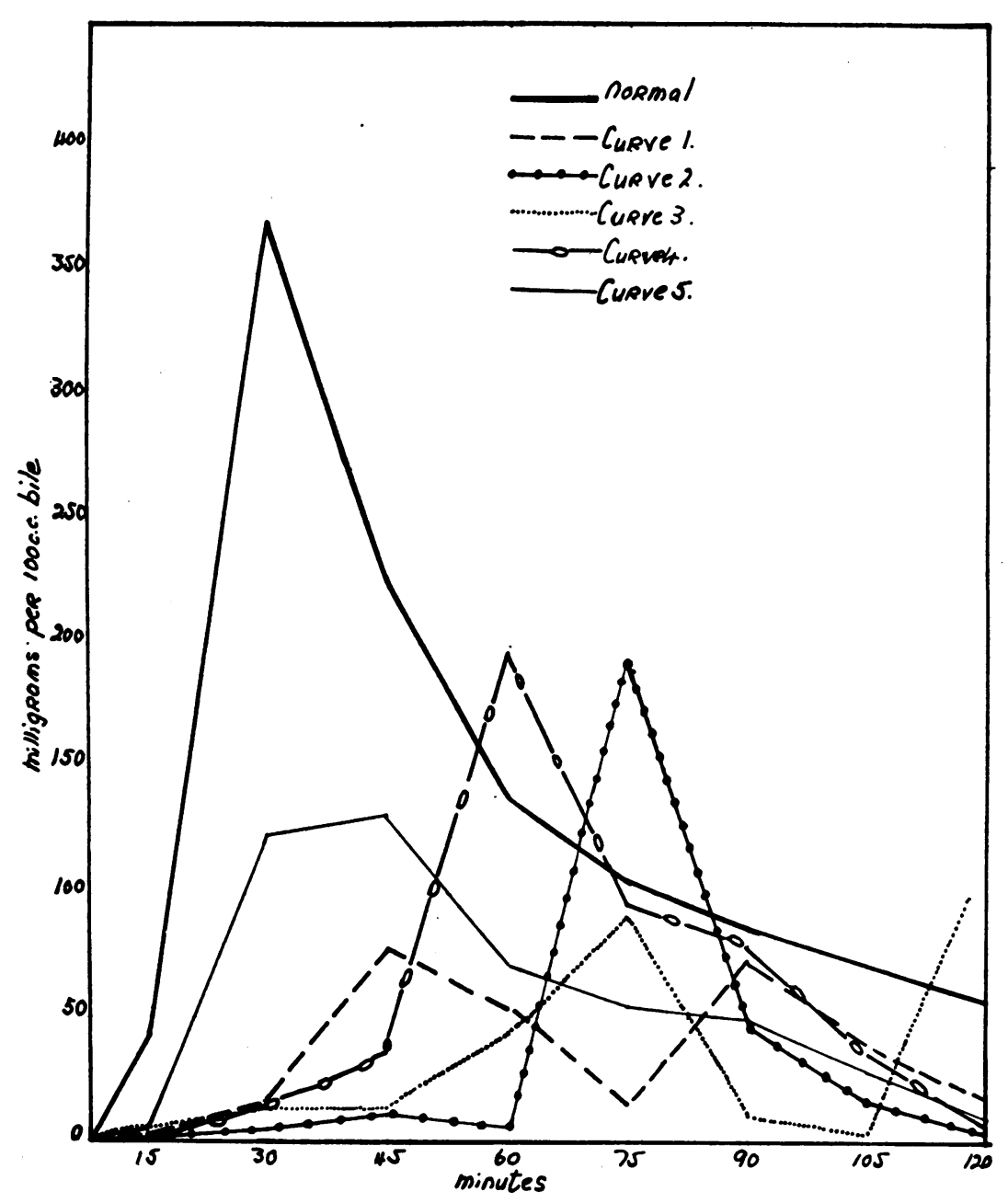

Fig. 4. Comparison of the Biliary Bromsulfalein Curves of Patient R. K. with Normal Curve

liver remained palpable and tender and the thymol turbidity test abnormal for approximately three months (Table IV).

The initial biliary bromsulfalein test, which was performed after the patient had received about two months' treatment, showed severe impairment of hepatic function (Figure 4). Therapy was continued and liver function, according to the biliary bromsulfalein test, improved gradually. The quantity of dye excreted at one and two hours returned to within essentially normal limits over a period of one month, but the concentration curve remained abnormal.

Reference to Table $\mathrm{V}$ shows that no significant trend was demonstrated in any of the four groups described above. Actually there was a fairly equal
TABLE $\mathbf{V}$

\begin{tabular}{l|c|c|c|c|c}
\hline \hline \multicolumn{1}{c|}{ Group } & I & II & III & IV & Total \\
\hline $\begin{array}{l}\text { Number of cases } \\
\text { Biliary bromsulfalein test } \\
\text { normal at 3 months }\end{array}$ & 4 & 6 & 7 & 8 & 25 \\
$\begin{array}{l}\text { Biliary bromsulfalein test } \\
\text { abnormal at 3 months }\end{array}$ & 2 & 3 & 2 & 3 & 10 \\
$\begin{array}{l}\text { History of relapse } \\
\begin{array}{l}\text { Serum jaundice } \\
\text { Infectious hepatitis. }\end{array}\end{array}$ & -3 & -3 & 4 & 5 & 9 \\
\hline
\end{tabular}

distribution of those with infectious hepatitis and serum jaundice in whom liver function returned to normal. Those patients who suffered relapse fell exclusively into Groups III and IV, and manifested abnormal routine tests as well as abnormal biliary bromsulfalein tests. However, persistent 
abnormal liver function occurred with equal frequency in patients in whom there was no history of relapse.

\section{DISCUSSION}

The actual incidence of chronic liver impairment following hepatitis is not well established, and many authors feel that if more sensitive liver function tests were available a higher incidence would be found. Soffer and Paulson (2), using the bilirubin tolerance test, which they considered highly sensitive, found residual impairment of hepatic function in nine of 11 patients, eight of whom had had an acute attack of hepatitis three to 18 years previously. Mateer and his colleagues (21), using a group of newer sensitive tests, found abnormal liver function in $62 \mathrm{pa}-$ tients without clinical or other laboratory evidence of gall-bladder or liver disease. The liver function tests became normal on an average after four months of intensive therapy designed to improve hepatic function.

Kunkel, Labby and Hoagland (10) ran multiple, serial liver function studies at weekly intervals on 350 patients with acute infectious hepatitis. They emphasize the importance of the plasma bilirubin level, the bromsulfalein retention and the thymol turbidity reaction of the serum for following the various types of persistent impairment of the liver. They found eight patients, or 2.3 per cent, who did not recover completely after more than one year's time.

The actual transition from hepatitis to cirrhosis of the liver had been demonstrated by serial biopsy by Iverson and Roholm (16), Dible, McMichael and Sherlock (17), and Hoffbauer (31). Out of 40 patients in whom Mallory performed liver biopsy because of persistence of symptoms following hepatitis, 15 were normal, 10 were doubtful and 15 showed changes similar to a normal convalescent group; that is, histological evidence of periportal and interlobular inflammation and focal hyalin necrosis (32). From these studies it is clear that liver disease can be demonstrated by biopsy when histological change is present, but it seems possible that minimal physiological impairment may not always be manifested by structural change. Similarly it seems possible that minimal structural change could exist in the absence of physiologic abnormality.
In the present study of a group of 25 patients convalescing from hepatitis the results of routine liver function tests were normal or equivocal, but the initial biliary bromsulfalein test showed impaired liver function in all of the patients. By using this test at approximately weekly intervals minimal to moderate impairment of hepatic function was shown to return to normal in 15 patients (60 per cent) when adequate liver therapy was continued long enough. Ten patients (40 per cent) continued to have impaired liver function despite intensive therapy, for at least three months.

\section{CONCLUSION}

It appears from this study that the biliary bromsulfalein test is a reliably sensitive test of liver function of considerable help in studying selected patients in whom minimal hepatic functional impairment is suspected.

\section{BIBLIOGRAPHY}

1. Polack, E., Chronic hepatitis in young persons, with or without intermittent jaundice. Acta med. Scandinav., 1938, 93, 614.

2. Soffer, L. J., and Paulson, M., Residual hepatic damage in catarrhal jaundice as determined by the bilirubin excretion test. Arch. Int. Med., 1934, 53, 809.

3. Abramson, L., On hepatitis chronica in younger persons. Acta med. Scandinav., 1941, 108, 561.

4. Kornberg, A., Latent liver disease in persons recovered from catarrhal jaundice and in otherwise normal medical students as revealed by the bilirubin excretion test. J. Clin. Invest., 1942, 21, 299.

5. Altschule, M.D., and Gilligan, D. R., Chronic latent hepatitis following catarrhal jaundice. New England J. Med., 1944, 231, 315.

6. Fishman, A. P., Persistent hepatitis in patients returning from overseas. Bull. U. S. Army M. Dept., 1945, 4, 457.

7. Barker, M. H., Capps, R. B., and Allen, F. W., Chronic hepatitis in the Mediterranean theatre, a new clinical syndrome. J. A. M. A., 1945, 129, 653 .

8. Neefe, J. R., Results of hepatic tests in chronic hepatitis without jaundice. Gastroenterology, 1946, 7,1.

9. Kunkel, H. G., and Hoagland, C. L., Persistence of elevated values for the thymol turbidity test following infectious hepatitis. Proc. Soc. Exper. Biol. \& Med., 1946, 62, 258.

10. Kunkel, H. G., Labby, D. H., and Hoagland, C. L., Chronic liver disease following infectious hepatitis. I. Abnormal convalescence from initial attack. Ann. Int. Med., 1947, 27, 202.

11. Marion, D. F., Delayed convalescence following acute hepatitis. Gastroenterology, 1947, 8, 717. 
12. Krarup, N. B., and Roholm, $K$., The development of cirrhosis of the liver after acute hepatitis, elucidated by aspiration biopsy. Acta med. Scandinav., 1941, 108, 306.

13. Watson, C. J., and Hoffbauer, F. W., The problem of prolonged hepatitis with particular reference to the cholangiolitic type and to the development of cholangiolitic cirrhosis of liver. Ann. Int. Med., 1946, 25, 195.

14. Neefe, J. R., Stokes, J., Jr., Garber, R. S., and Gellis, S. S., Studies on the relationship of the hepatitis virus to persistent symptoms, disability, and hepatic disturbance ("chronic hepatitis syndrome") following acute infectious hepatitis. J. Clin. Invest., 1947, 26, 329.

15. Klatskin, G., and Rappaport, E. M., Late residuals in presumably cured acute infectious hepatitis. Ann. Int. Med., 1947, 26, 13.

16. Iversen, P., and Roholm, K., On aspiration biopsy of liver, with remarks on its diagnostic significance. Acta med. Scandinav., 1939, 102, 1.

17. Dible, J. H., McMichael, J., Jr., and Sherlock, S. P. V., Pathology of acute hepatitis, aspiration, biopsy studies of epidemic, arsenotherapy and serum jaundice. Lancet, 1943, 2, 402.

18. Sherlock, S., and Walsh, V., The post-hepatitis syndrome. Lancet, 1946, 2, 482.

19. Davis, W. D., Scott, R. W., and Lund, H. Z., Needle biopsy of the liver. Am. J. M. Sc., 1946, 212, 449.

20. Sherlock, S. P. V., Biochemical investigations in liver disease: some correlations with hepatic histology. J. Path. \& Bact., 1946, 58, 523.

21. Mateer, J. G., Baltz, J. I., Steele, H. H., Brouwer, S. W., and Colvert, J. R., Chronic subclinical impairment of the liver. J. A. M. A., 1947, 133, 909.

22. Cantarow, A., and Wirts, C. W., Excretion of bromsulfalein in the bile. Proc. Soc. Exper. Biol. \& Med., 1941, 47, 252.
23. Wirts, C. W., Jr., and Cantarow, A., A study of the excretion of bromsulphthalein in the bile. Am. J. Digest. Dis., 1942, 9, 101.

24. Dragstedt, C. A., and Mills, M. A., Bilirubinemia and bromsulphalein retention. Proc. Soc. Exper. Biol. \& Med., 1936, 34, 467.

25. Watson, C. J., and Rappaport, E. M., A comparison of the results obtained with the Hanger cephalincholesterol flocculation test and the Maclagan thymol turbidity test in patients with liver disease. J. Lab. \& Clin. Med., 1945, 30, 983.

26. Recant, L., Chargaff, E., and Hanger, F. M., Comparison of the cephalin-cholesterol flocculation with the thymol turbidity test. Proc. Soc. Exper. Biol. \& Med., 1945, 60, 245.

27. Cantarow, A., and Wirts, C. W., Jr., The effect of dog's bile, certain bile acids and India ink on bilirubinemia and the excretion of bromsulfalein. Am. J. Digest. Dis., 1943, 10, 261.

28. Snape, W. J., Wirts, C. W., Jr., and Cantarow, A., Comparison of two types of permanent external bile-fistula dogs for studying liver function. Proc. Soc. Exper. Biol. \& Med., 1947, 66, 468.

29. Shank, R. E., and Hoagland, C. L., A modified method for the quantitative determination of the thymol turbidity reaction of serum. J. Biol. Chem.; 1946, $162,133$.

30. Mateer, J. G., Baltz, J. I., Comanduras, P. D., Steele, H. H., and Brouwer, S. W., Further advances in liver function tests. Gastroenterology, 1947, 8, 52.

31. Hoffbauer, F. W., A correlation of the composite liver function studies with histologic changes in the liver as noted in biopsy material. J. Lab. \& Clin. Med., 1945, 30, 381.

32. Mallory, T. B., The pathology of epidemic hepatitis. J. A. M. A., 1947, 134, 655. 